Сокальська О. В., кандидат юридичних наук, доцент e-mail:co2001@ukr.net ORCID: 0000-0001-8737-0829

\title{
НЕКРИТИЧНЕ ЦИТУВАННЯ ТА ВІДВЕРТИЙ ПЛАГІАТ В ІСТОРИКО-ТЮРМОЗНАВЧИХ ДОСЛІДЖЕННЯХ (ЧИ ЗАПРОВАДЖУВАВ І НІКЕЙСЬКИЙ СОБОР IHCTИTУT PROCURATORES PAUPERUM?)
}

У статі з'ясовано походження усталеної у тюрмознавчій літературі тези про запровадження Нікейським собором 325 p. інституту procuratores pauperum - осіб, які мали опікуватися бідними та ув'язненими, відвідувати їх, забезпечувати їжею, одягом і виступати поручителями. Встановлено, що вперше її висловив авторитетний прусський тюрмознавець Н.Г. Юліус у роботі 1828 р., грунтуючись на одному з приписів «арабських канонів», віднесених у збірках XVI-XVII ст. до настанов Нікейського собору. Приналежність цих канонів до I Вселенського собору була заперечена у кінці XIX ст. Однак це не завадило дослідникам історії в'язничних систем починаючи з кінця XIX ст. і до нині повторювати її у своїх роботах, часто без зазначення джерела.

Ключові слова: Нікейський собор 325 р.; procuratores pauperum; Н. Г. Юліус; арабські канони; історичні дослідження в галузі пенітенціаристики.

В статье исследуется происхождение укоренившегося в работах по истории тюрем тезиса об установлении Никейским собором в 325 г. института procuratores pauperum - опекунов бедных и заключённых. Выяснено, что впервые его высказал авторитетный прусский тюрьмовед Н.Г. Юлиус в 1828 г., основываясь на одном из предписаний «арабских канонов», отнесенных к постановлениям Никейского собора. В конце XIX в. учеными было доказано, что арабские каноны не являются подлинными. Однако, это не помешало исследователям истории тюремных учреждений повторять это утверждение в своих работах, часто без указания источника.

Ключевые слова: Никейский собор 325 г.; procuratores pauperum; Н. Г. Юлиус; арабские каноны; исторические исследования вопросов пенитенциаристики.

Постановка проблеми. Тюремні реформи у провідних країнах світу на зламі XVIII-XIX ст. зумовили як теоретичні студії 3 в'язничної проблематики, так і вивчення історичного досвіду: роботи провідних західних пенітенціаристів як правило супроводжувалися розлогими ретроспективними екскурсами. $\mathrm{y}$ радянський період інтерес до їх здобутків помітно згас, а вся світова історична пенітенціаристика була 
замінена 5-ти томною Iсторією царської тюрми М. М. Гернета.

3 актуалізацією реформ у сфері виконання покарань у пострадянський період, і фахівці з кримінальновиконавчого права, й історики права зацікавилися питаннями еволюції пенітенціарних систем. 3 небуття було повернуто праці тюрмознавців XIX - початку XX ст.: О. I. Полюмбецького, I. Я. Фойницького, Д. Г. Тальберга, С. В. Познишева та ін. Їх цитують, інколи запозичують цілі сторінки. Так конструюється «історія тюрми», написана уже нашими сучасниками, у якій, на жаль, як і в середині XIX ст., «первая мысль об учреждении пенитенциариев (домов покаяния) принадлежит Ж. Мабильону, монаху бенедектинского ордена XVII века» [1, с. 73; 2] або ж «У 1636 році чернець-бернардинець Жан Мобільон розробив проект влаштування тюрми, розрахованої на пробудження в душах злочинців каяття, який передбачав належні умови для життя, роботи і навіть садок для прогулянок» [3, с. 10] (порівняти у Д. Г. Тальберга: «монахъ Мобильонъ (1636 г.) предложилъ устроить для преступниковъ одиночное заключеніе для пробужденія раскаянія и садъ для молчаливыхъ работъ и прогулки» $[4$, с. 18]). Сумнівні, з точки зору наукової обгрунтованості, твердження про першість Ж. Мабільйона (Jean Mabillon) у справі організації пенітенціаріїв [5; 6], реалізацію Дж. Говардом тюремних реформ в Англії чи побудову перших пенітенціаріїв за зразком Паноптикону Дж. Бентама зустрічаємо не лише в публіцистичних нариcax, але й у фахових наукових джерелах, дисертаційних дослідженнях тощо.
Дивує, що нині, коли на відповідних ресурсах доступні не лише оригінальні праці Ж. Мабільйона, але й грунтовна стаття відомого американського кримінолога Т. Селліна (Thorsten Sellin) про його погляди на виправне покарання й тюрми монаших орденів [7], науковці все ще послуговуються виключно роботами російських тюрмознавців XIX ст. Важко собі уявити, що в природничих чи медичних науках дослідники обмежуються висновками авторитетів XIX ст., абсолютно ігноруючи здобутки науки за останні 120 років.

3 «історією» про Ж. Мабільйона як «основоположника пенітенціарних систем» за популярністю може конкурувати розповсюджена у дослідженнях 3 тюрмознавства і душпастирського служіння теза про запровадження 325 p. на I Вселенському соборі в м. Нікея інституту procuratores pauperum, у якому вбачають чи то витоки тюремного капеланства, чи то патронату. I якщо стаття Т. Селліна досить вичерпно окреслила роль Ж. Мабільйона у розвої пенітенціарних ідей, то щодо останнього твердження вважаємо необхідно провести грунтовний аналіз.

Постановка завдання. У цій статті ми спробуємо з'ясувати: першоджерело поширеної в історіографії тези про виникнення у IV ст. інституту procuratores pauperum (оскільки у більшості праць автори або цитують І. Я. Фойницького, або ж посилання загалом відсутні), чи дійсно це було одним із канонічних приписів Нікейського собору 325 р., i яким чином ця теза утвердилася в роботах з історичної пенітенціаристики.

Аналіз останніх досліджень і публікацій. Нами проаналізовано 
роботи тюрмознавців XIX ст. Н. Г. Юліуса, М. Греллета-Ваммі, Л.-М. Моро-Крістофа, Д. Г. Тальберга, I. Я. Фойницького, а також публікації 3 історії в'язниць та душпастирського служіння сучасних авторів, як вітчизняних, так і зарубіжних. Цінним джерелом стали збірки канонів XVII ст. С. Бініуса, Дж. Б. Сканаролі, а також дослідження настанов I Вселенського Нікейського собору К. Смірнова, Л. Воронова та ін.

Виклад основного матеріалу. Один із піонерів європейської тюремної науки, прусський фахівець Н. Г. Юліус (Nikolaus Heinrich Julius) у 1827 p. підготував цикл лекцій Vorlesungen über die gefängnisskunde (Leçons sur les prisons), що були опубліковані 1828 р. німецькою, а 1831 р. французькою мовами. У першій лекції автор подав загальний огляд стану тюрем та законодавчих приписів у стародавніх Греції та Римі, а також проаналізував вплив християнства на тюремну сферу. Саме у цій роботі вперше зустрічаємо тезу про запровадження Нікейським собором 325 р. інституту procuratores pauperum осіб (не обов'язково священнослужителів), які мали опікуватися бідними та ув'язненими, відвідувати їх, забезпечувати їжею та одягом, сприяти їх звільненню, виступати поручителями тощо. Як зазначав Др. Юліус, ще на соборі в Карфагені 253 р. було приписано: відвідувати стражденних віруючих не лише єпископам, але й представникам християнських общин, які повинні також опікуватися харчуванням ув'язнених [8; 9].

Учений зазначив, що 80 канон під назвою «De electione procuratoris pauperum et de officio ejus» додано до постанов Нікейського собору і його текст арабською виявлено лише в одному екземплярі [8]. У берлінському виданні лекцій у додатках автор наводить текст канону, посилаючись на збірку німецького католицького богослова С. Бініуса (Severin Binius) Concilia generalia et provincialia 1618 р., який цим каноном завершує настанови Нікейського собору [10]. Слід зазначити, що 80 канон містять також інші подібні збірки XVIXVII ст. $[11 ; 12]$.

У подальшому тезу Н. Г. Юліуса (безсумнівно одного 3 найавторитетніших пенітенціаристів Європи) про утвердження Нікейським собором інституту християнського тюремного опікунства повторюють й інші: 1838 p. швейцарець М. ГреллетВаммі (M. Grellet-Wammy) у роботі Manuel des prisons, ou Exposé historique, théorique et pratique du système pénitentiaire, 1851 р. відомий французький тюрмознавець Л.-М. МороКрістоф (Louis-Mathurin MoreauChristophe) у виданні Du problème de la misère et de sa solution chez les peuples anciens et modernes. Перший подає лише факти без посилання на джерело: «Нікейський собор у 325 р. запровадив чудову інституцію адвокатів для бідних (procuratores pauperum), чия місія - відвідувати ув'язнених і надавати їм все, що може знадобитися» [13]. Л.-М. МороКрістоф, наводячи текст з роботи Др. Юліуса, у посиланні ії не згадує, натомість доповнює викладене відсилками до інших джерел, зокрема дослідження Дю Буа про адвокатівопікунів бідних [14], у якому, слід зазначити, не йдеться про Нікейський собор, a procuratores pauperum згадуються лише в контексті практик захисту інтересів нижчих станів населення у Турині у XVII ст. [15]. 
Майбутній знаний тюрмознавець, а у 1874 р. ще студент юридичного факультету Університету Святого Володимира, Д. Г. Тальберг у розвідці, підготовленій під безпосереднім керівництвом професора О. Ф. Кістяківського [16] й опублікованій 1875 р., подає основні положення роботи Н. Г. Юліуса стосовно давньоримських тюрем (здійснивши фактично дослівний переклад берлінського видання лекцій), повсякчас посилаючись на нього і відтворюючи майже дослівно тезу прусського тюрмознавця про Нікейський собор 325 p. i procuratores pauperum. Автор підкріплює її виноскою, де у якості джерела зазначає ще й роботу Еберті (Eberty) 1858 p. і статтю I. Я. Фойницького Тюремная реформа и тюрьмоведение 1874 р. [4, с. $15 ; 17$, с. 459]. Таким чином, вказана інформація з'являється і в російській тюрмознавчій літературі: спершу у статті I. Я. Фойницького без зазначення джерела [18, с. 189190], а рік потому - в роботі Д. Г. Тальберга 3 посиланням на Н. Г. Юліуса.

Як бачимо, зацікавленість учених і практиків XIX ст. еволюцією в'язничних систем, їх активна міжнародна співпраця через пенітенціарні та тюремні конгреси, поширення серед науковців новітньої спеціальної літератури, зумовили той факт, що ідеї провідних пенітенціаристів Європи та США досить швидко розповсюджувалися і ставали складовою національних тюрмознавчих студій, що свідчить про їх тісну комунікацію і взаємодію, якій можна лише позаздрити з погляду сьогодення. Але некритичне ставлення до джерел і просте переписування робіт класиків призводило до тиражуван- ня недостовірних фактів, що і продовжується до нині.

Для дослідника, хоча б побічно знайомого з історією християнської церкви, очевидно, що 3 огляду на основоположність питань, які розглядалися на I Вселенському Нікейському соборі 325 р., навряд чи на ньому йшлося про опіку над ув'язненими. Хоча це питання і було у фокусі ранньохристиянських богословів. Ще Тертулліан висловлював підтримку ув'язненим мученикамхристиянам i закликав їх мужньо переносити страждання [19]. У Конституції імператорів Гонорія та Феодосія 409 р. у статті, що регламентувала в'язничний режим, харчування ув'язнених та обов'язкові інспекції тюрем суддями, також йшлося і про нагляд з боку єпископів [20]. Отже, питання патронату над ув'язненими християнами до легітимізації нової релігії як державної, а потому, загалом над особами, позбавленими волі, традиційно належало до інтересів церкви. А в подальшому ці повноваження були закріплені і світським законодавством. Однак, достовірні джерела, які б підтверджували, що фіксація цих функцій відбулася саме на Нікейському соборі, відсутні. Натомість вчені переконливо довели, що собор $325 \mathrm{p}$. постановив лише 20 канонів i про procuratores pauperum у них не йшлося [21].

Доктор Юліус своє твердження про procuratores pauperum підкріплював посиланням на текст 80 канону, зазначаючи, що його узято 3 арабських текстів постанов Нiкейського собору [8; 9]. Відповідно, у нього було канонічне джерело і не було, імовірно, сумнівів, що воно істинне і що ця інституція започаткована саме 325 р. Але, як встанови- 
ли дослідники наприкінці XIX ст., зокрема К. Й. Хефеле (C. J. Hefele) та К. Смірнов, так звані арабські канони, віднайдені у XVI ст., не мають жодного відношення до I Нікейського собору. За походженням вони належать до різних століть і різних Вселенських та Помісних соборів більш пізніх періодів $[22 ; 23$, с. 48]. На переконання К. Смірнова, думка про існування актів Нікейського собору, і актів достатньо об'ємних, у арабів 3'явилася унаслідок невірного уявлення про собор, зокрема, що він тривав три роки за участі близько 2000 єпископів. У результаті чого, 3 урахуванням значення Нікейського собору, вважалося, що і його актівпостанов має залишитися досить багато [21, с. 29-30]. Загалом, тенденція до віднесення церковних канонів інших соборів до постанов I Вселенського Нікейського собору, аби надати їм додаткової авторитетності, спостерігалася й у більш пізній період.

Інститут же procuratores pauperum - уповноважених управителів майном, що за тестаментами передавалося на користь бідноти, набув поширення, зокрема в італійських містах, лише починаючи з XIVXV ст. [24]. Також у джерелах зустрічаємо приписи (окремі з них наводить і Н. Г. Юліус у додатках до берлінського видання лекцій), що procuratores pauperum y XVI-XVII ст. опікувалися тюрмами [25]. Тому, дозволимо собі припущення, що під час перекладу «арабських канонів» було використано загальновідомий у той час термін procuratores pauperum, оскільки їх повноваження відповідали тому, що було описано в тексті 80 канону.
У кінці XIX ст. грунтовні дослідження постанов Нікейського собору вже було проведено. Вони переконливо доводили, що у 325 р. затверджено лише 20, а не 80 канонів, однак еліта європейської тюремної науки, імовірно, не дуже ними цікавилася.

1890 року на IV Міжнародному тюремному конгресі у СанктПетербурзі представник Бадена, очільник однієї 3 секцій конгресу Л. фон Ягеманн (Ludwig Hugo Franz von Jagemann) у виступі про запобігання та профілактику правопорушень, з поміж іншого, зазначив, що інституція procuratores pauperum, започаткована Нікейським собором 325 р. для відвідин тюрем, і нині існує в Іспанії, Гватемалі та поширюється у Новому світі [26].

А за рік до цього, 1889 р. побачив світ перший у Російській імперії підручник з тюрмознавства авторства професора I. Я. Фойницького Учение о наказании в связи с тюрьмоведением, у якому зазначалося (зрозуміло без посилання), що «уже Никейскій соборъ 325 г. возложилъ на procuratores pauperum, между прочимъ, обязанность заботиться объ улучшеніи матеріальнаго и нраветвеннаго состоянія заключенныхъ» $[27$, с. 310]. Навіть саме формулювання мало довести читачу, що питання тюремної опіки ієрархи християнства розглядали серед основоположних догматів церкви, разом із розробкою Символу віри, регламентацією процедури висвячення єпископів, засудженням аріанства, установленням окремого від іудеїв святкування Пасхи тощо [28].

Думається, саме завдяки популярності зазначеного підручника I. Я. Фойницького у сучасних роботах 
3 історії тюрми та душпастирського служіння $[1 ;$ 29-34] повсякчас з'являється теза про установлення 325 . Нікейським собором procuratores pauperum - опікунів ув'язнених і, досить часто, без посилання на джерело, що лише продовжує «традицію», започатковану професором Фойницьким, і підтверджує його статус класика тюрмознавства «на всі часи».

Цікаво, що про procuratores pauperum згадує майже у кожній своїй публікації російський автор, кандидат богослов'я 0. Скоморох, якому «сам бог велів би» поцікавитися канонічним першоджерелом, а не посилатися на Учение о наказание [35].

Такою собі «вишенькою на торті» російської історіографії з означеної проблематики можна вважати низку робіт М. Р. Арпентьєвої, яка гучно вивела словосполучення procuratores pauperum у назву публікацій, присвячених історії та сучасному стану патронату в Росії, таким чином, сама того не відаючи, зв'язала воєдино: християнську опіку давньоримських часів, середньовічних італійських адвокатів для бідних, тернистий шлях тюремного патронату в Російській імперії й атмосферу «конфронтации между администрацией и заключенными» в радянських ВТК $[36$, с. 1,13$]$. Як зазначає авторка: «Институт Procuratores Pauperum (попечения о бедных, горемычных) был учрежден в христианской Византии уже в 4-ом веке, аналогичные институты существовали и существуют в других религиях и конфессиях» $[36$, с. 5] (при цьому, джерело цього твердження, як і в іншій своїй роботі [1], або не наводить, або ж, як в одній із публікацій [37], посилається на підручник І. Я. Фойницького -
О. С.). Роздуми дослідниці над проблемами тюремного попечительства приводять ії до досить оригінальних висновків: «В России канал общественного попечения («procuratores pauperum») был перекрыт во время тюремной реформы под руководством К. К. Грота» [36, с. 9].

Щодо тверджень про виникнення інституту procuratores pauperum 325 р. 3 українськими та російськими авторами впевнено можуть конкурувати іспанські пенітенціаристи [38-41]. Так, А. Пая Ріко (Alberto Paya Rico) у дисертації, захищеній в Університеті Валенсії 2017 р., згадує про procuradores pauperum, зазначаючи, що про це писав Ф. Буено Арус (Francisco Bueno Arus), цитуючи! відомого іспанського криміналіста Е. Куельо Калона (Eugenio Cuello Calon) [40]. На останнього посилаються й у збірці з історії пенітенціарних систем, опублікованій у Мадриді 2010 р. [41]. Слід зазначити, що іспанські наукові розвідки відрізняє те, що їх автори хоча б роблять посилання, але все ж таки першоджерелом не надто цікавляться.

У статті польського дослідника Ц. Кундеревича (Cezary Kunderewicz) Traktowanie więźniów $w$ konstytucjach cesarskich z okresu dominatu 1977 p. y виносках-поясненнях до положень про благодійників у римських в'язницях теж згадується, що «W r. 325 sobór w Nicei nakazał, aby «procuratores pauperum» odwiedzali więzienia i ofiarowali swe usługi więźniom» [42].

Теза про procuratores pauperum і Нікейський собор поширилася і в Новому світі. 1999 року у Канаді опубліковано книгу про капеланське служіння в тюрмах та історію стано- 
влення пенітенціарної системи, яка, на нашу думку, попри те, що є досить змістовною, все ж має більше публіцистичний характер. Оскільки в ній відсутні посилання, то ж не дивно, що, повторюючи загалом уривок 3 роботи Др. Юліуса, автор Дж. Т. Л. Джеймс (J. T. L. James) не вказує джерело [43].

I якщо для дослідників 3 пострадянського простору, джерелом інформації частіше всього є підручник І. Я. Фойницького, то зарубіжні дослідники, найімовірніше, послуговуються роботами або національних «класиків тюрмознавства», або ж Н. Г. Юліуса та інших європейських пенітенціаристів XIX ст.

Висновки. Отже, некоректне запозичення тези про «запровадження Нікейським собором 325 р. інституту procuratores pauperum осіб, які мали опікуватися бідними та ув'язненими, відвідувати їх, забезпечувати їжею, одягом і виступати поручителями», що вперше була озвучена прусським тюрмознавцем Н. Г. Юліусом у 1827-1828 рр., ігнорування першоджерела, а саме 80 канону, i, як наслідок, досліджень про те, що «арабські канони», 3поміж яких і цей, не належали до ухвалених на Вселенському соборі 325 р., призвело до поширення іï як усталеної, загально відомої істини, що не потребує навіть підтвердження. Некритичне ставлення сучасних дослідників до наукових джерел більш ніж столітньої давності й, разом 3 тим, нехтування здобутками зарубіжної історичної та історикоправової науки призводить не до створення нових знань, а дублювання та примноження застарілої, недостовірної інформації, що часто-густо давно заперечена представниками суміжних галузей та іноземними колегами.

Перспективи подальших досліджень. Грунтуючись на висновках дослідників канонічних текстів, можна 3 великою долею вірогідності вважати, що приписи про обрання procuratores pauperum, які містив 80 канон, належать до більш пізніх настанов церкви й з'ясування періоду та обставин їх ухвалення $є$ перспективним напрямком для майбутніх досліджень.

\section{Список використаних джерел}

1. Арпентьева М. История и направления религиозной и психологической работы в уголовно-исполнительной системе. Аннали юридичної історії. 2020. Том 4. Випуск 1. C. 72-87. DOI: 10.38129/Ann.Yur.Ist.2020.4.1.72.

2. Пастырское служение в тюрьме в наше время. 1998. Глава III. Опыт тюремного служения инославных церквей. URL: http://helpprison.ru/2016/08/13/iz-nashegoarhiva-pastyrskoe-sluzhenie-v-tyurme-v-nashe-vremya-1998-god-chast-iii/ (дата звернення: 02.08.2020).

3. Пахомов І. В., Григоренко А. М. Соціально-виховна робота із засудженими та особами, взятими під варту : навчальний посібник / Білоцерківський центр ПКП ДКВС України; за заг. ред. д. пед. н., проф. М. О. Супруна, 2019. 296 с.

4. Тальберг Д. Г. Исторический очерк тюремной реформы и современные системы европейских тюрем. Киев, 1875.70 с.

5. Бодюл $Є$. М. Проблеми доктринального визначення поняття «пенітенціарна система». Науковий вісник Національної академії внутрішніх справ. 2013. № 1. С. 3132. 
6. Калюжний Р. А., Резник I. І. Пенітенціарій. Юридична енциклопедія: В 6 т. / Редкол.: Ю. Ю. С. Шемшученко (голова редкол.) та ін. Київ : «Українська енциклопедія», 1998. URL: https://leksika.com.ua/16010717/legal/penitentsiariy (дата звернення: 06.09.2020).

7. Sellin T. Dom Jean Mabillon: A Prison Reformer of the Seventeenth Century. Journal of the American Institute of Criminal Law and Criminology. 1927. Vol. 17. No. 4. P. 581-602. DOI: $10.2307 / 1134349$.

8. Julius N. H. Leçons sur les prisons: présentées en forme de cours au public du Berlin en l'année 1827. Tome premier. Paris, 1831. P. 244.

9. Vorlesungen über die gefängnisskunde, oder über die verbesserung der gefängnisse und sittliche besserung der gefangenen, entlassenen sträflinge u.s.w., gehalten im frühlinge $1827 \mathrm{zu}$ Berlin, von Nikolaus Heinrich Julius. Berlin, 1828. S. 14. URL: https://catalog.hathitrust.org/Record/008430043 (дата звернення: 09.09.2020).

10. Binius S. Concilia generalia et provincialia. Vol. 1. 1618. P. 364.

11. Apostolicarum constitutionum et catholicae doctrinae libri VIII, Francisco Turriano interprete e graeco (etc.) Accesserunt canones concilii Nicaeni 80 ex arabico in latinum conversi et responsa Nicolai I. ad consulta Bulgarorum. Christophorus Plantinus,1578. P. 27.

12. Giovanni Battista Scanaroli. De visitatione carceratorum libri tres. Quibus omnia ad visitationem, ... explanantur. ... Summorum pontificum hac super re constitutiones, iura, Rotae Romanae decisiones passim toto opere allegatae in calce, appendicis loco, subiunguntur. Typis Reuerendae Camerae Apostolicae, 1655. P. 65.

13. Grellet-Wammy M. Manuel des prisons, ou Exposé historique, théorique et pratique du système pénitentiaire. Paris-Genève, 1838. P. 6.

14. Moreau-Christophe L.-M. Du problème de la misère et de sa solution chez les peuples anciens et modernes. T. 2. Paris. 1851. P. 321.

15. Du Beux J. C. M. G. Études sur l'institution de l'Avocat des Pauvres, et sur les moyens de défense des indigens dans les procés civils et criminels en France, en Sardaigne, et dans les principaux pays de l'Europe. Paris, 1847. P. 40.

16. Берзін П. С. Київська школа кримінального права (1834-1960рр.): історико-правове дослідження : монографія. 2-ге вид., переробл. і доповн. Київ : ВД «Дакор», 2013. С. 435.

17. Тальберг Д. Г. Исторический очерк тюремной реформы и современные системы европейских тюрем. Университетские известия. 1875. Т. 15. № 7. С. 445-478.

18. Фойницкий И. Я. Тюремная реформа и тюрьмоведение. Журнал гражданского и уголовного права. 1874. Кн. 1. (январь-февраль). С. 185-206.

19. Тертуллиан. Избранные сочинения: Пер. с лат./Общ. ред. и сост. А. А. Столярова. Москва : Издательская группа «Прогресс», «Культура», 1994. С. 274.

20. CTh. 9.3.7 Imperatoris Theodosii Codex URL: http://ancientrome.ru/ius/ library/codex/theod/liber09.htm\#3 (дата звернення: 11.09.2020).

21. Смирнов К. Н. Обозрение источников истории Первого вселенского никейского собора : Сочинение на степень магистра богословия К. Смирнова. Ярославль : типолитогр. Г. Фальк, 1888. 358, IV c.

22. Воронов Л. Документы и акты, входящие в состав «Деяний первого Вселенского Собора 325 года». URL: https://azbyka.ru/otechnik/Liverij_Voronov/dokumenty-iakty-vkhodjashhie-v-sostav-dejanij-pervogo-vselenskogo-sobora-325-goda/ (дата звернення: 10.08.2020).

23. Смелова Н. С. Правила Первого Вселенского Никейского собора по рукописи Сир. 34 из собрания ИВР РАН. Письменные памятники востока. 2009. № 2(11). C. $42-65$. 
24. Duval S. L'argent des pauvres. L'institution de l'executor testamentorum et procurator pauperum à Pise entre 1350 et 1424. Mélanges de l'École française de Rome : Moyen Âge. 2013. № 125-1 DOI:10.4000/mefrm.1157.

25. S.D.N.D. Paul I Papae Qvinti Constitutio Super Reformatione Tribunalium Vrbis. Rome. 1612. P. 26.

26. Actes du Congrès pénitentiaire international de Saint-Pétersbourg, 1890, T. 1. Louis Guillaume. Bureau de la Commission d'organisation du Congrès, 1892. P. 739.

27. Фойницкий И. Я. Учение о наказании в связи с тюрьмоведением. СПб : Типография Министерства путей Сообщения, 1889. 503 с.

28. Див.: Правила святого первого вселенского никейского собора. Правила Православной Церкви с толкованиями Никодима, епископа Далматинско-Истрийского. Перевод с сербского. Том 1. Издательство «Отчий дом», Москва : 2001. С. 173-236.

29. Протоиерей Сергий Сальцов. История и современность миссии Русской Православной Церкви среди заключенных. Философско-педагогические и религиозные основания образования в России: история и современность : Шестые Международные Покровские образовательные чтения, 23-25 октября 2007 года / под ред. В.А. Беляевой, Ю.В. Орловой ; Ряз. гос. ун-т им. С. А. Есенина. Рязань, 2008. С. 111-124.

30. Ходыкин И. Миссионерское служение в местах лишения свободы. Диссертация на соискание ученой степени кандидата богословия. Московская духовная академия. Сергиев Посад, 2001. С. 23.

31. Турчина О. С. Громадський вплив як один з основних засобів виправлення і ресоціалізації засуджених : дис. ... канд. юрид. наук. Харків. нац. ун-т внутр. справ. Харків, 2018. С. 110.

32. Бадира В. А. Виправлення жінок, засуджених до позбавлення волі, як мета покарання : дис. ... канд. юрид. наук. Гуманітарний університет «Запорізький інститут державного та муніципального управління». Запоріжжя, 2005. 244 с.

33. Голоборотько Д. Є. Етапи становлення та розвитку інституту тюремних священнослужителів (капеланів). Науковий вісник Дніпропетровського державного університету внутрішніх справ. 2017. № 3. С. 82.

34. Дука О. А., Супрун М. О. Актуальні питання співробітництва української православної церкви та Державної пенітенціарної служби України: минуле й сьогодення. Науковий вісник Інституту кримінально-виконавчої служби. 2014. № 2. С. 66.

35. Скоморох 0. Тюремное служение Русской Православной Церкви в местах лишения свободы. История и современное состояние. Уголовно-исполнительное право. 2010. № 2. С. 73-75.

36. Арпентьева M. P. Procuratores Pauperum: история и современность попечительства в России. Личность и общество: нравственная идея в ценностном мире современного человека: Материалы всероссийской научно-практической конференции с международным участием «Мокроносовские чтения-2017» (г. Екатеринбург, 25 ноября 2017 г.). Екатеринбург : УрФУ, 2017. С. 3-16. URL: https://elar.urfu.ru/ bitstream/10995/60015/1/lo_01.pdf (дата звернення: 12.09.2020). Публікація з ідентичною назвою вміщена також у збірці: Всероссийская научно-практическая конференция «Актуальные проблемы права в России». Хасавюрт 2017. URL: http://hasdgu.ru/nauka/sbor_konf/aktualnye_problemy_prava_2017.pdf (дата звернення: 12.09.2020).

37. Арпентьева М. Р. Духовное здоровье личности и общества: религиозная помощь заключённым. Шестнадцатый Славянский научный собор «Урал. Православие. Культура». Кирилло-Мефодиевская традиция в культуре России: материалы всерос. науч.-практ. конф. / сост. О. В. Терехова; Челяб. гос. ин-т культуры, Адм. Челяб. обл., Челяб. митрополия Русской православной церкви. Челябинск : ЧГИК, 2018. С. 252. 
38. Gómez M. I. G. Locura entre rejas. P. 11 URL: https://www.ramemur.com/ files/Ingreso\%20Miembros/Isabel_Garca_Discurso_de_Ingreso_Web.pdf (дата звернення: 11.09.2020).

39. Da Sofía Muñumer Domingo Trabajo de fin de grado en trabajo social "panorama actual de la intervención social penitenciaria" la reinserción y la prevención de la reincidencia. Facultad de educación y trabajo social Universidad de Valladolid Curso 2015-2016. P. 13. URL: https://core.ac.uk/download/pdf/211102969.pdf (дата звернення: 11.09.2020).

40. Payá Rico A. La asistencia religiosa en centros penitenciarios y de internamiento de extranjeros. Tesis doctoral. Universitat de València. Facultat de dret 2017. P. 65.

41. Internamiento de menores y sistema penitenciario. 2010. Madrid. P. 285.

42. Kunderewicz C. Traktowanie więźniów w konstytucjach cesarskich z okresu dominatu. Prawo Kanoniczne: kwartalnik prawno-historyczny. 1977. 20/3-4. C. 283.

43. James J. T. L. A Living tradition Penitentiary Chaplaincy. Ottawa. Division Correctional Service of Canada, 1990. P. 32.

\section{References}

Arpenteva, M. (2020). Istoriya i napravleniya religioznoj i psihologicheskoj raboty v ugolovno-ispolnitelnoj sisteme. Annali yuridichnoyi istoriyi, 4, 1, 72-87. DOI: 10.38129/Ann.Yur.Ist.2020.4.1.72 [in Russian].

Pahomov, I. V., Grigorenko, A. M. (2019). Socialno-vihovna robota iz zasudzhenimi ta osobami, vzyatimi pid vartu / Bilocerkivskij centr PKP DKVS Ukrayini; za zag. red. d. ped. n., prof. M. O. Supruna [in Ukrainian].

Talberg, D. G. (1875). Istoricheskij ocherk tyuremnoj reformy i sovremennye sistemy evropejskih tyurem. Kiev [in Russian].

Bodyul, Ye. M. (2013). Problemi doktrinalnogo viznachennya ponyattya «penitenciarna sistema». Naukovij visnik Nacionalnoyi akademiyi vnutrishnih sprav, 1, 31-32 [in Ukrainian].

Kalyuzhnij, R. A., Reznik, I. I. (1998). Penitenciarij. Yuridichna enciklopediya: V 6 t. / Redkol.: Yu. Yu. S. Shemshuchenko (golova redkol.). Kiyiv: «Ukrayinska enciklopediya». URL: https://leksika.com.ua/16010717/legal/penitentsiariy (accessed: 06.09.2020) [in Ukrainian].

Sellin, T. (1927). Dom Jean Mabillon: A Prison Reformer of the Seventeenth Century. Journal of the American Institute of Criminal Law and Criminology. Vol. 17. No. 4. pp. 581-602. DOI: $10.2307 / 1134349$.

Julius, N. H. (1831). Leçons sur les prisons: présentées en forme de cours au public du Berlin en l'année 1827. Tome premier. Paris.

Vorlesungen über die gefängnisskunde, oder über die verbesserung der gefängnisse und sittliche besserung der gefangenen, entlassenen sträflinge u.s.w., gehalten im frühlinge 1827 zu Berlin, von Nikolaus Heinrich Julius. Berlin, 1828. URL: https://catalog.hathitrust.org/Record/008430043 (accessed: 09.09.2020).

Grellet-Wammy, M. (1838). Manuel des prisons, ou Exposé historique, théorique et pratique du système pénitentiaire. Paris-Genève.

Moreau-Christophe, L.-M. (1851). Du problème de la misère et de sa solution chez les peuples anciens et modernes. T. 2. Paris.

Du Beux, J. C. M. G. (1847). Études sur l'institution de l'Avocat des Pauvres, et sur les moyens de défense des indigens dans les procés civils et criminels en France, en Sardaigne, et dans les principaux pays de l'Europe. Paris.

Berzin, P. S. (2013). Kiyivska shkola kriminalnogo prava (1834-1960 rr.): istorikopravove doslidzhennya. 2-ge vid., pererobl. i dopovn. Kiyiv: VD «Dakor» [in Ukrainian]. 
Talberg, D. G. (1875). Istoricheskij ocherk tyuremnoj reformy i sovremennye sistemy evropejskih tyurem. Universitetskie izvestiya, 15, 7, 445-478 [in Russian].

Fojnickij, I. Ya. (1874). Tyuremnaya reforma i tyurmovedenie. Zhurnal grazhdanskogo i ugolovnogo prava, 1, 185-206 [in Russian].

Stolyarova, A. A. (red.). (1994). Tertullian. Izbrannye sochineniya. Moskva: Izdatelskaya gruppa «Progress», «Kultura» [in Russian].

Smirnov, K. N. (1888). Obozrenie istochnikov istorii Pervogo vselenskogo nikejskogo sobora. Yaroslavl: tipolitogr. G. Falk [in Russian].

Voronov, L. Dokumenty i akty, vhodyashie $v$ sostav «Deyanij pervogo Vselenskogo Sobora 325 goda». URL: https://azbyka.ru/otechnik/Liverij_Voronov/dokumenty-i-aktyvkhodjashhie-v-sostav-dejanij-pervogo-vselenskogo-sobora-325-goda/ (accessed: 10.09.2020) [in Russian].

Smelova, N. S. (2009). Pravila Pervogo Vselenskogo Nikejskogo sobora po rukopisi Sir. 34 iz sobraniya IVR RAN. Pismennye pamyatniki vostoka, 2 (11), 42-65 [in Russian].

Duval, S. (2013). L'argent des pauvres. L'institution de l'executor testamentorum et procurator pauperum à Pise entre 1350 et 1424. Mélanges de l'École française de Rome : Moyen Âge. № 125-1. DOI:10.4000/mefrm.1157.

Actes du Congrès pénitentiaire international de Saint-Pétersbourg, 1890, T.1. Louis Guillaume. Bureau de la Commission d'organisation du Congrès, 1892.

Fojnickij, I. Ya. (1889). Uchenie o nakazanii $v$ svyazi s tyurmovedeniem. SPb: Tipografiya Ministerstva putej Soobsheniya [in Russian].

Pravila svyatogo pervogo vselenskogo nikejskogo sobora. (2001). Pravila Pravoslavnoj Cerkvi s tolkovaniyami Nikodima, episkopa Dalmatinsko-Istrijskogo. Perevod s serbskogo. T. 1. Izdatelstvo «Otchij dom», Moskva [in Russian].

Salcov, Sergij (2008). Istoriya i sovremennost missii Russkoj Pravoslavnoj Cerkvi sredi zaklyuchennyh. Filosofsko-pedagogicheskie i religioznye osnovaniya obrazovaniya $v$ Rossii: istoriya i sovremennost: Shestye Mezhdunarodnye Pokrovskie obrazovatelnye chteniya, 23-25 oktyabrya 2007 goda / pod red. V. A. Belyaevoj, Yu.V. Orlovoj; Ryaz. gos. un-t im. S. A. Esenina. Ryazan, 111-124 [in Russian].

Hodykin, I. (2001). Missionerskoe sluzhenie v mestah lisheniya svobody. (Dissertaciya na soiskanie uchenoj stepeni kandidata bogosloviya). Moskovskaya duhovnaya akademiya. Sergiev Posad [in Russian].

Turchina, O. S. (2018). Gromadskij vpliv yak odin $z$ osnovnih zasobiv vipravlennya $i$ resocializaciyi zasudzhenih. (Dis. ... kand. yurid. nauk). Harkiv. nac. un-t vnutr. sprav. Harkiv [in Ukrainian].

Badira, V. A. (2005). Vipravlennya zhinok, zasudzhenih do pozbavlennya voli, yak meta pokarannya. (Dis. ... kand. yurid. nauk). Gumanitarnij universitet «Zaporizkij institut derzhavnogo ta municipalnogo upravlinnya». Zaporizhzhya [in Ukrainian].

Goloborotko, D. Ye. (2017). Etapi stanovlennya ta rozvitku institutu tyuremnih svyashennosluzhiteliv (kapelaniv). Naukovij visnik Dnipropetrovskogo derzhavnogo universitetu vnutrishnih sprav, 3, 82 [in Ukrainian].

Duka, O. A., Suprun, M. O. (2014). Aktualni pitannya spivrobitnictva ukrayinskoyi pravoslavnoyi cerkvi ta Derzhavnoyi penitenciarnoyi sluzhbi Ukrayini: minule j sogodennya. Naukovij visnik Institutu kriminalno-vikonavchoyi sluzhbi, 2, 66 [in Ukrainian].

Skomoroh, 0. (2010).Tyuremnoe sluzhenie Russkoj Pravoslavnoj Cerkvi v mestah lisheniya svobody. Istoriya i sovremennoe sostoyanie. Ugolovno-ispolnitelnoe pravo, 2, 73-75 [in Russian].

Arpenteva, M. R. (2017). Procuratores Pauperum: istoriya i sovremennost popechitelstva $\mathrm{v}$ Rossii. Lichnost $i$ obshestvo: nravstvennaya ideya $v$ cennostnom mire sovremennogo cheloveka: materialy vserossijskoj nauchno-prakticheskoj konferencii $\mathrm{s}$ mezhdunarodnym uchastiem «Mokronosovskie chteniya-2017» (g. Ekaterinburg, 25 noyabrya 
2017 g.). Ekaterinburg: UrFU, 2017. S. 3-16. URL: https://elar.urfu.ru/bitstream/10995/ 60015/1/lo_01.pdf (accessed: 12.09.2020) [in Russian].

Arpenteva, M. R. (2018). Duhovnoe zdorove lichnosti i obshestva: religioznaya pomosh zaklyuchyonnym. Shestnadcatyj Slavyanskij nauchnyj sobor «Ural. Pravoslavie. Kultura». Kirillo-Mefodievskaya tradiciya v kulture Rossii: materialy vseros. nauch.-prakt. konf. / sost. O. V. Terehova; Chelyab. gos. in-t kultury, Adm. Chelyab. obl., Chelyab. mitropoliya Russkoj pravoslavnoj cerkvi. Chelyabinsk: ChGIK, [in Russian].

Gómez, M. I. G. Locura entre rejas. URL: https://www.ramemur.com/ files/Ingreso\%20Miembros/Isabel_Garca_Discurso_de_Ingreso_Web.pdf (accessed: 01.09.2020).

Muñumer Domingo, Sofía Trabajo de fin de grado en trabajo social "panorama actual de la intervención social penitenciaria" la reinserción y la prevención de la reincidencia. Facultad de educación y trabajo social Universidad de Valladolid Curso 2015-2016. URL: https://core.ac.uk/download/pdf/211102969.pdf (accessed: 11.09.2020).

Payá Rico, A. (2017). La asistencia religiosa en centros penitenciarios y de internamiento de extranjeros (Tesis doctoral). Universitat de València. Facultat de dret.

Internamiento de menores y sistema penitenciario. 2010. Madrid.

Kunderewicz, C. (1977). Traktowanie więźniów w konstytucjach cesarskich z okresu dominatu. Prawo Kanoniczne: kwartalnik prawno-historyczny, 20/3-4, 283.

James, J. T. L. (1990). A Living Tradition Penitentiary Chaplaincy. Ottawa. Division Correctional Service of Canada.

o. Sokalska, PhD in Law, Associate Professor

e-mail:co2001@ukr.net; ORCID: 0000-0001-8737-0829

\section{Uncritical citations and outright plagiarism in the history of prisons studies (Did the First Council of Nicaea introduce the institute of procuratores pauperum?)}

The article explores the origins of the thesis that the First Council of Nicaea established in $325 \mathrm{AD}$ the institution of procuratores pauperum - the guardians of the poor and prisoners - which is entrenched in research on the history of prisons. It was found that it was first expressed by the authoritative Prussian scientist Nikolaus Heinrich Julius in lectures published in 1828. The scientist made his conclusion on the basis of the prescriptions of the Arab canons referred to the decrees of the First Council of Nicaea. Later this statement was repeated by M. Grellet-Wammy, Louis-Mathurin Moreau-Christophe, Ivan Foinitsky, Dmitry Talberg in their works. At the end of the XIX century scholars have proven that the Arab canons are not authentic. However, from the end of the 19th century and to the present day this did not prevent researchers of the history of prisons from repeating in their works, often without specifying the source, the thesis of the establishment of the institute of procuratores pauperum by the First Council of Nicaea.

Ignoring the original source, namely the 80 canons, and research that the Arab canons did not belong to those approved by the First Council of Nicaea in year 325 , led to the spread of the idea of introducing procuratores pauperum as an established, well-known truth that does not require confirmation. The uncritical attitude of modern researchers to scientific sources, that are more than a century old, 
and the neglect of the achievements of foreign historical and historical-legal science does not lead to the creation of new knowledge, but to a duplication and multiplication of outdated, unreliable information.

Keywords: The First Council of Nicaea 325; procuratores pauperum; Nikolaus Heinrich Julius; Arabic canons; prison history research. 